\title{
Jordan's Public Policy Response to COVID-19 Pandemic: Insight and Policy Analysis
}

\author{
Wa'ed Alshoubaki ${ }^{1}$ • Michael Harris ${ }^{2}$
}

Accepted: 14 September 2021 / Published online: 6 October 2021

(c) The Author(s), under exclusive licence to Springer Science+Business Media, LLC, part of Springer Nature 2021

\begin{abstract}
The aim of this study was to gain an understanding of how the Jordanian government has responded and continues to respond to the COVID-19 pandemic. It utilizes the interpretive policy analysis approach through document analysis. The analysis showed that Jordan created social protection policies to assist people who lost their jobs or whose work was suspended due to the coronavirus. The economic policies build solidarity and facilitate the private sector's recovery. The health care measures firmly applied included lockdown, wearing masks, and restrictions on gatherings and public events. Jordan uses hard power and imposes sanctions on any violation that threatens the lives of others.
\end{abstract}

Keywords COVID-19 $\cdot$ Jordan $\cdot$ National plan · Policy analysis

After China registered the first death case from coronavirus on January 9, 2020, the novel infectious disease spread very quickly, reaching the United States, the United Kingdom, Italy, Germany, Japan, Canada, and France by the first week of February. After the infection accelerated, registering 20,000 confirmed cases and 1,000 deaths in the European region, the World Health Organization (WHO) declared the outbreak an official pandemic (Baldwin \& Di Mauro, 2020). COVID-19 hit the world's countries very hard, becoming a global health crisis that negatively affects social, economic, and development conditions in unprecedented ways (Kovacevic \& Jahic, 2020). The United Nations Development Programme (United Nations Development

Wa'ed Alshoubaki

w.alshoubaki@ju.edu.jo

Michael Harris

mharris50@tnstate.edu

1 Department of Public Administration, The University of Jordan, Queen Rania Street, Amman 11942, Jordan

2 Department of Public Administration, Office of Academic Affairs, Tennessee State University, 3500 John A. Merritt Blvd, Nashville, TN 37209, USA 
Programme, 2020b) contends that the economic and developmental downsides of this pandemic are comparable to levels of deprivation during the early 1980s recession.

The states' responses to contain the pandemic, to deal with its repercussions, to reduce the vulnerabilities, and to build capacity are varied in their preparedness plans based on social, economic, political, and cultural factors.

Analyzing the governmental response to COVID-19 in the Middle East, specifically Jordan, yields an understanding of the crisis's impact on a developing country and the Jordanian government's response in light of scarce resources, poor economic conditions, and social vulnerability. Jordan started its precaution procedures after the WHO declared the outbreak pandemic on February 27, 2020. Following that, Jordan initiated COVID-19 screening at airports and implemented a 14-day quarantine for positive cases on March 2, 2020, and the first case was confirmed on March 19, 2020. Although at the beginning of the pandemic, Jordanian government procedures were considered some of the strictest governmental measures in dealing with the pandemic to keep the people safe, these measures had social and economic shortcomings for people's well-being. Therefore, it is essential to understand the Jordanian government's response perspectives and the governmental determinants to make decisions in light of the reality of the crisis. The examination of this study is built upon an analysis in response to the following questions: (a) What is Jordan's approach to managing the COVID-19 crisis? (b) To what extent are the Jordanian health care system and economic situation capable of handling the COVID-19 pandemic? To answer these questions, The study utilized an interpretive approach through documentary analysis of published governmental documents to build a rigorous understanding to inform Jordanian policies and decision-making practices while addressing the COVID-19 crisis. This study makes a significant contribution to the literature on this unprecedented crisis because it stipulates a way of understanding how and why Jordan's government formulated certain policies and measures in responding to the crisis. Furthermore, utilizing the interpretive policy analysis approach frames Jordan's response on a macro and comprehensive scale.

\section{Background}

Jordan is a parliamentary country with a hereditary monarchy ruling regime consisting of executive, legislative, and judicial authorities. The executive authority gains its democratic legitimacy from its ability to inspire confidence in the legislature, and it is held accountable to the parliament (Hague \& Harrop, 2006). In essence, the executive authority consists of the king, who appoints the prime minister to develop his cabinet (Massadeh, 1999). The legislative authority is a bicameral system including the lower chamber, which is elected by the citizens, and the upper chamber, appointed by the king (Massadeh, 1999). The judicial authority is an independent entity represented by the courts of law and varies in type and degree (United Nations, 2004). Moreover, Jordan is a unitary state, wherein the central government delegates authority to subnational parties, such as governorates and municipalities, to implement public policies established by the central government (Hague 
\& Harrop, 2006). The subnational government of Jordan consists of governorates, which are administrative divisions headed by a governor appointed by the minister of the interior (Decentralization Law 49, 2015), and municipalities, which are civic institutions with legal personhood and financial and administrative independence (Municipality Law 41, 2015).

The crisis management system in Jordan was demarcated through the Jordan Constitution, Article (124), which, in the case of an event occurring that requires defending Jordan in emergencies through issuing the Defense Law, authorizes the government to take necessary measures and procedures to ensure the country's defense. For this reason, Jordan has managed the coronavirus crisis through implementing the 1992 Defense Law No. (13), which pertains to defending the country from any national security or general safety threats, namely war, social disorder, and an outbreak of a plague or epidemic (Article 2:A). According to Article 3(A), the prime minister is entrusted to implement this law and to take the necessary measures and procedures to secure public safety and defend Jordan without being bound by the provisions of the regular laws in force.

\section{Jordan's Crisis Administration System During the Pandemic}

The National Centre for Security and Crisis Management (NCSCM) adapts streamlined interagency coordination mechanisms across government departments, the private sector, and nongovernment organizations (NGOs), including international humanitarian aid agencies, to deal with a crisis (Regulation No. 20 for the year 2015: issued in accordance with Article 120 of the Constitution). In doing so, the Jordanian government has unified and coordinated efforts by composing a coronavirus crisis cell within the NCSCM's structure, including permanent and related interval stakeholders depending on the decisions and measures under implementation. To illustrate, in ensuring the continuation of the public supply chains and stockpiles, this emergency cell consisted of the Ministry of the Interior, the Ministry of Health, the Army Command, the Public Security Directorate, the Gendarmerie Directorate, the Civil Defense Directorate, the Ministry of Information, the Ministry of Foreign Affairs, the Ministry of Agriculture, and the Ministry of Industry, Trade and Supply. As for the transitional members in the first phase of the crisis, when the state used hotels as places for quarantining those entering Jordan, efforts were coordinated with the Hotel Association and the Ministry of Tourism. Alongside this was the participation of the Jordanian National Committee for Epidemics, which is responsible for researching epidemics, assessing the epidemiological situation in Jordan, and recommending policy mechanisms to address an epidemic's development. In managing the coronavirus crisis, this committee created a coherent network consisting of health care professionals in the Ministry of Health, university medical faculties, the WHO, the Royal Medical Services, and the private sector to provide a set of recommendations and consultations regarding the governmental policies and procedures to contain the epidemic (Ministry of Health, 2020). In addition to the National Policies Council's (NPC's) consultation role in terms of preparedness 


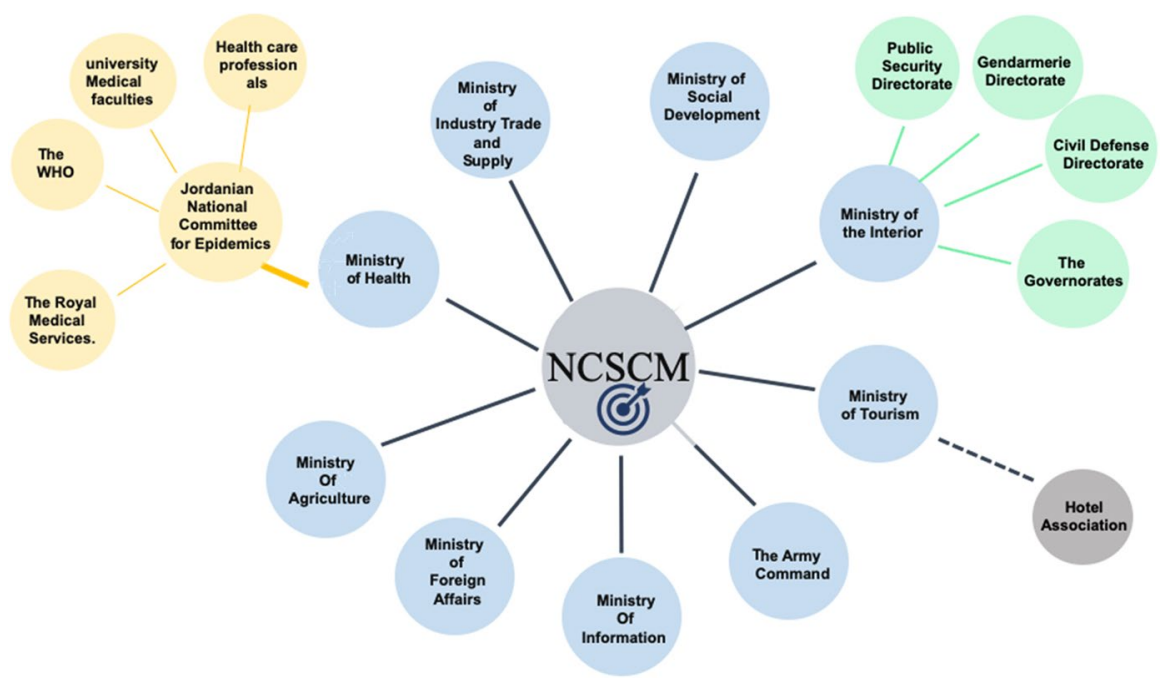

Fig. 1 The Structure of Jordan's Crisis Administration During the Pandemic. Note. Source: By authors based on Regulation No. 20 for the year 2015 and defense orders 2020

and the response plan, it was significant in coordinating among governmental units and emphasizing social protection consideration. Figure 1 shows the structure of Jordan's crisis administration during the pandemic through the NCSCM.

In line with an emphasis on understanding the Jordanian crisis management system, the legal structure raised the level of preparedness to deal with the coronavirus crisis. The 1999 Civil Defense Law No. (18) stipulates that the Council of Civil Defense intervenes in the case of unordinary events, sudden cases, or emergencies (Article 1). For example, in the period of full lockdown, the Civil Defense was responsible for transporting all those in need of medical services and medication (UNICEF, 2020). Moreover, the 2015 Decentralization Law and Municipality Law facilitated the regional response to the pandemic through policymaking and service delivery. Declaring a governorate the epicenter of COVID-19, the governorates were quarantined, and the governor became the leading head of Jordan's pandemic response and the senior on epidemiological committee empowered with responsibilities of the Minister of Health within the geographic borders of the governorates. However, the governors had to report to the Minister of Interior, and each ministerial team coordinated with the related directorates and local agencies to ensure policy measures were executed (Health Care Accreditation Council, 2020).

In its efforts to create a national preparedness and response plan, the Jordanian government utilized the existing legal and public policies to address the crisis needs. Thus, building the resilience approach meant adopting a coherent participatory tactic to manage the coronavirus crisis, which then transformed into public policies that covered the epidemic response containment measures and socioeconomic consequences, as will be discussed in the analysis section. 


\section{Literature Review}

The analysis of governmental responses to COVID-19 provides a better understanding about the development of policies to control the spread of the disease. Imtyaz et al. (2020) classified governmental responses to the pandemic aiming to curtail the spread of the virus and treat those infected. They argued that lockdown, tracing cases, and testing are effective policies to limit the spread of the virus, ensure better control, and reduce the mortality rate. However, these measures have socioeconomic consequences due to the resulting disruption of economic transactions and high unemployment, in addition to the direct effect on health systems (Fakhruddin et al., 2020). The researchers predicted that recovery issues would encompass macro-scale changes in national and global policies and be led by politics, economics, and science in a holistic approach. Davidovitz et al. (2021) analyzed the implications of the governmental response to COVID-19 for street-level bureaucrats and found that policy responses have imposed extra duties on police officers, teachers, and physicians. This burden is coupled with policy uncertainty, higher risk exposure, and expanded discretion.

Indeed, states vary in their response policies based on governance capacity and sociopolitical and economic context. According to Christensen and Laegreid (2020), Norway handled the pandemic successfully due to competent politicians, professional bureaucrats, and public trust in the government, intertwined with good economic conditions and a strong welfare state. Norwegian policies are based on suppression strategies such as quarantining, limiting social gatherings, mandating masks, avoiding unnecessary travel, and closing schools, kindergartens, universities, and shops other than grocery stores. These policies are followed by economic support measures that add to governance capacity in terms of health care and coordination capacities between the government and organizations (Christensen \& Laegreid, 2020). Generally, the root causes of this success in responding to the crisis depend on a combination of democratic legitimacy, governmental capacity, and open communication with citizens through daily media coverage (Christensen \& Laegreid, 2020). Similarly, South Korea has managed the pandemic well by acknowledging the extent of the problem and establishing a diagnostic capacity to deal with the spread of the virus (Oh et al., 2020). South Korea applied forceful measures to prevent transmission and reallocate clinical resources to effectively respond to potential regional pressure. These health care measures were implemented in parallel with economic support to facilitate the recovery of the most impacted sectors (Oh et al., 2020). Additionally, Farazmand and Danaeefard (2021) examined Iranian policies for handling the pandemic and pointed out Iran's effective response in spite of being under the United States' economic sanctions, including for medicines. The core success of Iran's response is due to self-sufficiency and citizens' engagement in dealing with the pandemic. Government-citizen coordination has facilitated preventing the spread of the disease and reduced its consequences via a national campaign against economic sanctions (Farazmand \& Danaeefard, 2021). Iran has produced diagnostic kits and drugs for patients, established centralized and decentralized approaches 
with an emphasis on citizen participation, fortified the health care system, and involved the army in response plans (Farazmand \& Danaeefard, 2021).

From a different perspective, Capano (2020) argued that existing state characteristics shape policy formulation and governmental capacity to deal with the pandemic. Capano used Italy as an example to support his argument, considering the lack of specific preparedness for this kind of emergency and how the current policy approach and political system affect Italian management strategies. In addition, Vardavas et al. (2021) pointed to the effect of cultural differences and social norms in shaping policies designed to eradicate COVID-19. Contextually, the pandemic has hit South Asian states harshly, including India, Sri Lanka, and Nepal. Upadhaya et al. (2020) asserted that the pandemic has negatively impacted informal and service sectors and decreased remittances, which increases inequalities among people in South Asia. Ghosh et al. (2020) discussed Indian procedures in dealing with the crisis and found that health care measures to fight the spread of the virus have obstructed the economy and quality of life despite the positive impact on the environment. Lone and Ahmad (2020) claimed that vulnerable groups in Africa will be affected most severely by the pandemic and its consequences. They raised concerns regarding African states' capacity to deal with this pandemic due to limited testing capacities, lack of qualified and trained health care staff, shortages in medical and personal protective equipment, and lack of public health funds.

Most studies have addressed governmental responses by analyzing governments' capacity to deal with the pandemic. Regarding the role of previous government efforts in dealing with similar emergencies and disasters, Capano et al. (2020) analyzed factors that contribute to governmental responses. They confirmed that policies are shaped by governmental approaches to dealing with previous epidemics; these past crises play a vital role when considering lessons learned, in addition to the leadership style, role of civil society in the state, and recognition of vulnerable groups. Lastly, the novelty of the COVID-19 pandemic has required an understanding of a variety of policies, which are subjugated by aggressive and authoritative tools such as lockdown, movement restrictions, tracing and regulating of business, and incorporation of measures for information management, advisories, and warnings (Goyal \& Howlett, 2021).

\section{Theoretical Perspective}

The calamity and complexity of the pandemic can be explained through various scientific lenses to deepen our understanding of governmental responses. To illustrate, disaster theory contends that a disaster is "what causes or is likely to cause any harm to the lives, bodies and property of citizens and the state" (Kim \& Sohn, 2018, p. 24). In the United Nations' International Strategy for Disaster Reduction (2002), hazards originating from nature are called hydrometerological or biological disasters. According to Boin (2005), the traditional concept of disaster does not address modern adversity, as it is not constrained by geographic borders and time span. The impact of a contemporary disaster is prolonged, and it could be entangled with other problems. 
Petak (1985) suggested the phases model of disaster management, which include disaster mitigation, preparedness, response, and recovery. Petak identified the role of government and stakeholders in each phase of dealing with a disaster. Disaster management is characterized by uncertainty and a need for integration in handling the situation; it is also subject to urgency (Moe \& Pathranarakul, 2006).

A distinct theory that identifies dynamic and unpredictable conditions built upon the chaos and complexity theories is the surprise management theory. According to Farazmand (2009), surprise management theory discards the routine and expected and aims to respond to unpredictable events with flexibility and adaptability. It amalgamates the features of an authoritative, collaborative, participative, and adoptive approach, emphasizing self-organization and hyper-flexibility. In essence, the conditions for surprise management incorporate the foci as areas of crisis, whether based on political, social, disaster, or international relations. Loci are the locations of the crisis in an organization or governance areas. Regarding key decision makers and participants in the surprise management process, it certainly demands extraordinarily disciplined authority and power (Farazmand, 2007). Surprise management requires a crisis condition, experience, rigorous training, the authority to act, and sufficient resources to operate (Farazmand, 2007). Therefore, building a capacity for surprise management relies on public authorization to institutionalize this capacity at all governmental levels and development of scientific specialization in managing chaos to ensure better preparation for such situations (Farazmand, 2009).

\section{Methodology}

Scholars point to the role of policy analysis in providing an understanding about how and why governments formulate policies and their consequences. Browne et al. (2018) discussed policy analysis as a research method, considering it a powerful tool to understand the use of research evidence in policymaking and to generate an enhanced understanding of the values, interest, and context of policy decisions. In this study, it is critical to identify how to investigate and understand Jordan's government response to COVID-19 as an unprecedented multidimensional crisis. Indeed, the interpretive approach for policy analysis emphasizes "the problem representation, and how the framing of the policy problems shapes the array of possible policy responses" (Browne et al., 2018, p. 7). The interpretive approach entails different policy orientations, as many studies have concluded (Colebatch, 2002; Fischer, 2003; Fisher et al., 2015; Hajer \& Wagenaar, 2003; Yanow, 2000). However, for the sake of this study, the focus was on explaining the contextual factors of the Jordanian government's COVID-19 response through a vulnerability assessment and analyzing the essential content of the government preparedness plan and response.

This interpretive approach utilizes a document analysis of published government policy documents, as Bryman (2016) pointed out that a state's documents contain large amounts of rigorous information that a researcher could utilize. Browne et al. (2018) asserted that the interpretive approach utilizes "interviews; document analysis; ethnographic methods; historical methods; discourse analysis; narrative analysis" (p. 3). For instance, Thompson et al. (2013) employed UK 


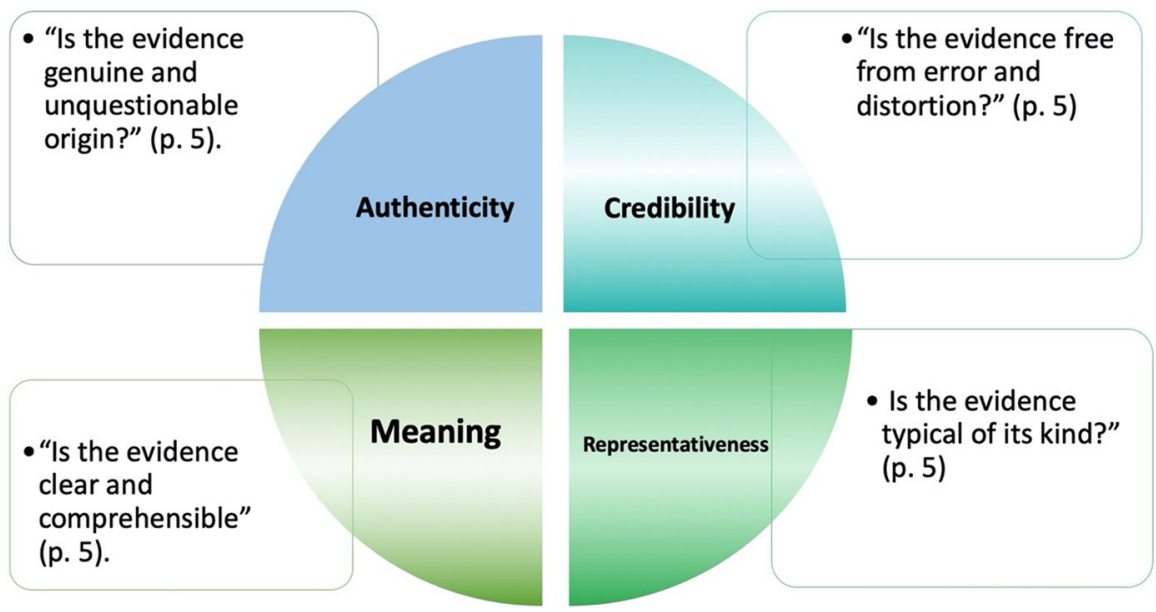

Fig. 2 Scott's Governmental Documents Criteria

government policy documents to understand how East London stood as a problem area through analyzing several House of Commons sources. Their analysis of governmental documents proved the relationship between neoliberal rhetoric and the rationalization of the considerable investment involved. Similarly, this study analyzed the documents and statistical data of global NGOs such as the UNDP, OECD, and Oxford's Our World in Data. Adopting the analysis of official documents deriving from governments achieves Scott's (1990) quality of document criteria, which are shown in Fig. 2.

This study sought to answer the research by analyzing Jordanian governmental documents, as the government documents are authentic, clear, and comprehensive data sources. However, some scholars are concerned about government documents' credibility and if these documents are biased. Bryman (2016) cautioned researchers in interpreting such documents and treating them as a depiction of reality. As for representativeness, official documents that address an extraordinary crisis that recently occurred are unique, making them a distinguished source. Generally speaking, the representativeness in qualitative research is less of a concern because no case can achieve this criterion in a statistical sense (Bryman, 2016).

\section{Data Sources}

This study utilized two data sources to accomplish the two paths of analysis. First, it analyzed the defense orders and all of their related procedures between March 19, 2020, and December 15, 2020. Second, it analyzed data from the UNDP, the World Bank, the WHO, International Monetary Fund (IMF), and the Department of Statistics-Jordan to conduct the vulnerability analysis of the Jordanian healthcare system and economic situation. 


\section{Step | Gathering and sorting governmental documents from earliest to latest to} understand the gradual trajectory and sequence of the response.

Step II Conducting a preliminary reading of the documents to recognize a contextual theme of the governmental response to COVID-19.

Step III Indexing the noticed themes that developed, including health care protection, economic protection, social protection, and the durability of basic service.

Step V Reviewing the index and matching it with the corpus emphasis on the data's meanings.

Fig. 3 Document Analysis Procedures

\section{Document Analysis Procedures}

To interpret the documents of this study, the document analysis was utilized as the most prevailing approach. This approach involves looking into the documents' underlying themes and providing answers to research questions through extracted and organized data. This interpretation occurred based on the procedures in Fig. 3.

Conclusively, the analysis conducted on the 2020 Defense Order No. (1) through 2020 Defense Order No. (24) provided heightened understanding of the governmental preparedness and response measures, as described in the next section.

\section{Findings and Analysis}

COVID-19's rapid spread forced Jordan to adopt a rigorous, rapid response to prevent any further spread. Analyzing governmental documents, mainly the defense orders and their related governmental proclamations as policy instruments, to deal with the pandemic can explain the national preparedness plan and response through health care, economic protection, social protection, and the continuation of basic services. 
Table 1 Main Health Care Protection Policies

\begin{tabular}{ll}
\hline The protection measures & The policy source \\
\hline $\begin{array}{l}\text { Social distancing }(1.5 \mathrm{~m}) \\
\text { Wearing a mask and gloves }\end{array}$ & $\begin{array}{l}\text { Defense Order No. 11 } \\
\text { Defense Order No. 11 } \\
20 \% \text { reductions in workers of private institutions and 50\% reduc- } \\
\text { tions in public institution employees }\end{array}$ \\
$\begin{array}{l}\text { Mandate of a (PCR) test and 14-day quarantine for all travelers } \\
\text { Yellow and red countries, which are high-risk countries with } \\
\begin{array}{l}10+\text { and } 25+\text { new cases a day per 100,000 people, respectively, } \\
\text { are subjected to a 7-day home quarantine }\end{array}\end{array}$ & $\begin{array}{l}\text { Ministry of Health, March 2020 } \\
\end{array}$
\end{tabular}

\section{Health Care Protection}

\section{Lockdown Policies}

At the beginning of the pandemic, Jordan adopted a full-scale lockdown to overcome what the region and the whole world were going through from an emergency health perspective and to prevent the spread of the virus.

The first lockdown measure entailed closing all stores on the morning of Tuesday, March 1, 2020, and prohibiting people from moving and roaming in all regions of the Kingdom, starting at 7:00 a.m. on Saturday, March 21, 2020—specific times were announced during which citizens could fulfill their essential needs and with specific mechanisms (Defense Order No. 2). As for emergency medical cases, citizens had to inform the General Security and the Civil Defense to take the necessary measures to protect their health and safety in the proper manner (Defense Order No. 2 ). Vital governmental sectors, whose work requires continuance in the workplace and institutions and is determined by the concerned minister, the public and private health care sector, and the banking sector were excluded from this policy (Communication No. 2). Table 1 classifies the main health care protection policies.

The changes in the lockdown policies and other health care protection measures were noticed through the change in the Stringency Index, ${ }^{1}$ shown in Fig. 4.

\section{Testing Policies}

By the end of December 2020, Jordan had performed 3,175,555 tests and created epidemiological investigation teams in all Jordanian governorates to accomplish the goals of contact tracing (Ministry of Health, 2020). The WHO (2020) recommended contact tracing to identify, assess, and manage the people exposed to the coronavirus to prevent transmission, therefore breaking the chain of infection. Generally

\footnotetext{
1 The Stringency Index is a composite measure based on several response indicators including school closures, workplace closures, and travel bans.
} 


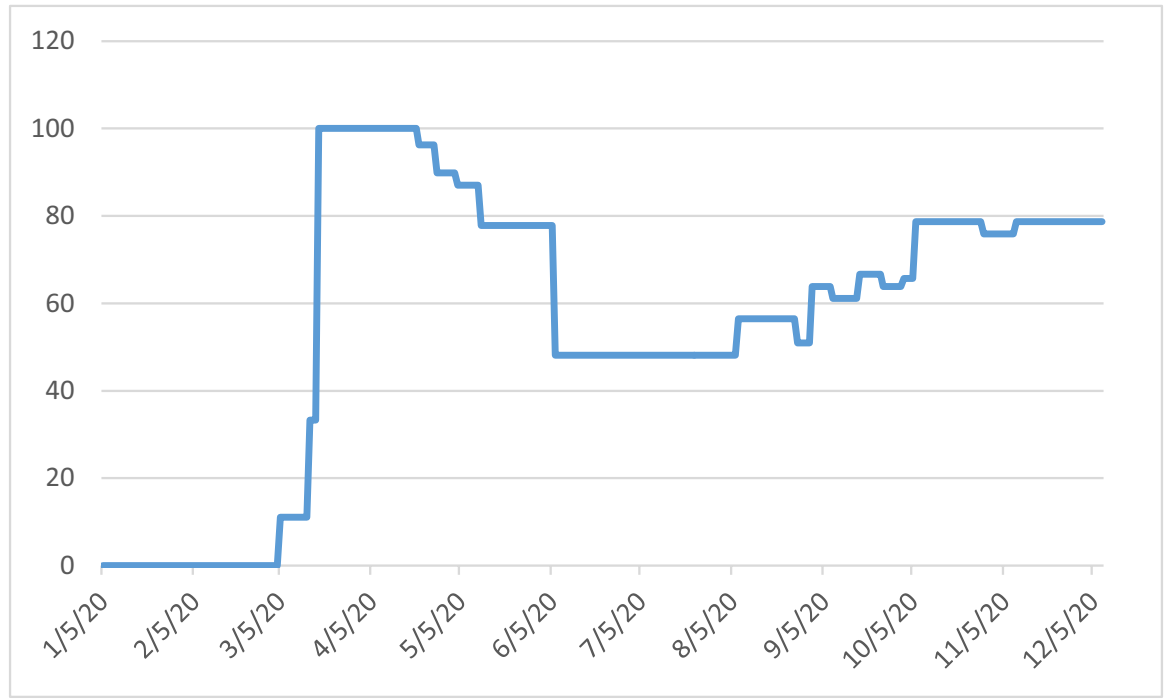

Fig. 4 Stringency Index of Jordan, Jan.-Dec. 2020. Note. Stringency Index scale value from 0 to 100 $(100=$ strictest response). Source: The Oxford COVID-19 Government Response Tracker (2020)

speaking, Jordan built a strong testing and tracing capacity, recording the highest testing rate among the middle income in the Middle East and North Africa due to the collaboration between private and public laboratories (Ben Mimoune et al., 2020).

\section{Restrictions on Gathering and Cancelling Public Events}

The Jordanian government prohibited holding, organizing, and participating in gatherings, including wedding parties, social invitations, and gatherings of all kinds for more than 20 people. Additionally, in the event of death, the government forbade establishing mourning houses and limited the matter to participating in the burial ceremonies with a minimal number of people, provided they adhered to social distancing standards, wore masks, and did not shake hands (Defense Order No. 16; Defense Order 22).

\section{Quarantine and Curfew Policies}

The Jordanian government obliged any person to immediately disclose their infection or contact with a person infected with the coronavirus to the competent authorities. The Ministry of Health issued measures and actions to prevent the infection's spread, including quarantine procedures and home isolation, as well as in places competent authorities specified, such as restaurants, recreation areas, and so on (Defense Order No. 8; Defense Order 20). 


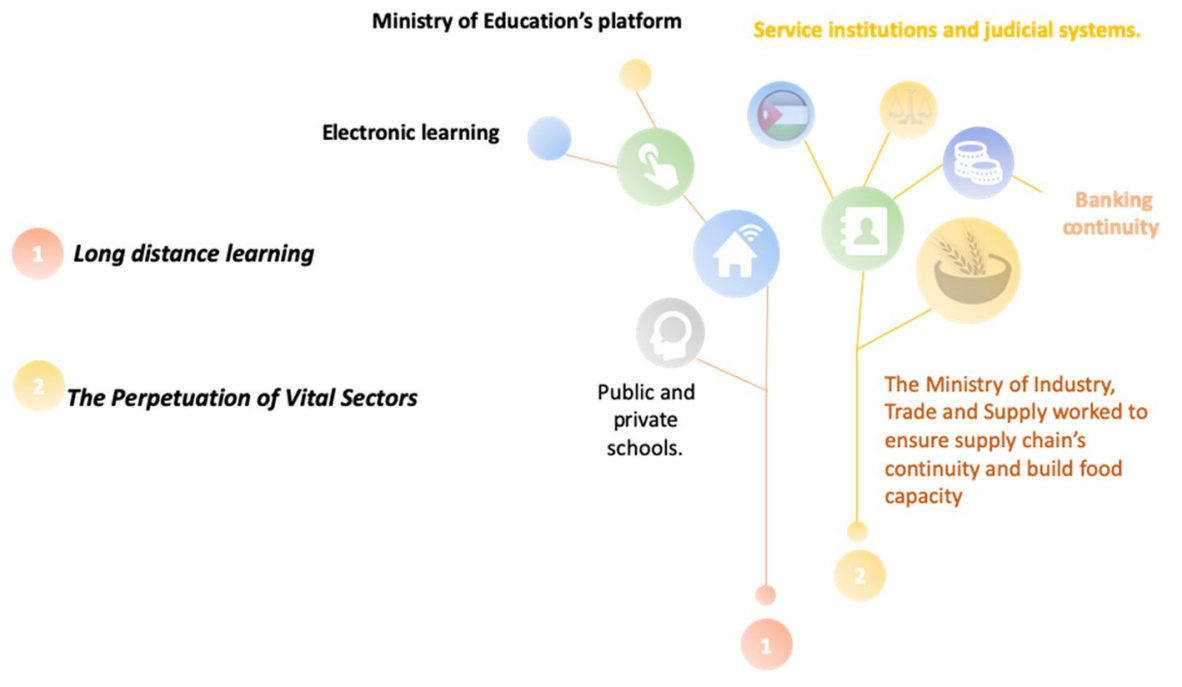

Fig. 5 The Continuity of Basic Services. Note. Source: Defense orders No. 7 and 21

The Jordanian government obliged the infected to sign a pledge to comply with the epidemiological investigation committees' instructions and issued orders, and not to hinder or impede their implementation. The commitment that the suspect or the person in contact with a person infected with the virus signed included a commitment to self-quarantine, home quarantine, and noncontact with others during the period that the competent authorities prescribed (Defense Order No 8, Article 1: 4).

\section{The Continuation of Basic Services}

During the governmental precaution measures to prevent the spread of the coronavirus, the Jordanian government implemented major strategies to ensure the continuity of basic services such as education, banking, and other vital public and private sectors in light of the prevailing exceptional circumstances. The continuity of basic services is illustrated in Fig. 5.

\section{Social Protection}

Due to the havoc that COVID-19 caused and the repercussions of the precaution measures on individuals and households, the Jordanian government developed social programs to alleviate the vulnerabilities that resulted from the pandemic. Table 2 summarizes the main social protection policies. 
Table 2 Social Programs in the Pandemic Response

The Social Program The Beneficiaries

A Nation's Effort Jordanian households harmed by the pandemic

The Supporting Program I Jordanian employees whose service was terminated or whose work was suspended and who had social security subscriptions of less than 36 months

The Supporting Program II The insured Jordanians and non-Jordanians in Jordan whose disbursement requests were submitted from the savings balance account of the employee's unemployment insurance

The Economic Empower- Insured Jordanians in the private sector and insured civilians working in ment Program II any of the public sector facilities, municipalities, or the Greater Amman Municipality

Note. Source: Defense orders No. 4, 9, 14 and 15.

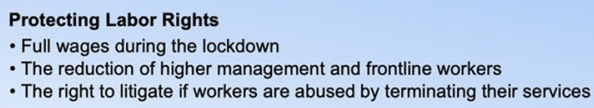

Fig. 6 The Policies of Economic Support During the Pandemic. Note. Source: Defense Order No. 4, 9, 14 and 15

\section{Economic Protection}

Whereas the curfew aimed to protect Jordanians and their health, the economic repercussions of this measure were obvious. The government intervention was significant to reduce the negative economic impacts on employers, private sector companies, and their workers. Figure 6 presents the policies of economic support during the pandemic. From this insight, the government directed its efforts to enable the economy to recover after the end of the crisis and to orient them toward the gradual opening and operating of economic sectors through various supportive programs and measures, which included those in Fig. 6. Indeed, considering the average monthly wages, which are around $\$ 678$, the financial support 
Table 3 Number of COVID-19 Cases and Deaths in Jordan, 2020

\begin{tabular}{lllllllllllll}
\hline & Jan & Feb & March & April & May & June & July & Aug & Sept & Oct & Nov & Dec \\
\hline Cases & 0 & 0 & 274 & 179 & 286 & 393 & 61 & 841 & 9,791 & 60,782 & 146,823 & 75,064 \\
Deaths & 0 & 0 & 5 & 3 & 1 & 0 & 2 & 4 & 46 & 768 & 1922 & 1083 \\
\hline
\end{tabular}

Note. Source: World Health Organization.

Table 4 Selected Indicators of Jordan's Health Care System Preparedness

\begin{tabular}{llll}
\hline Physicians & Nurses and midwives & Hospital beds & $\begin{array}{l}\text { Current } \\
\text { health } \\
\text { expenditure }\end{array}$ \\
\hline (per 10,000 people) & (per 10,000 people) & (per 10,000 people) & (\% of GDP) \\
$2010-2018$ & $2010-2018$ & $2010-2018$ & 2018 \\
23.4 & 34 & 14 & 8.1 \\
\hline
\end{tabular}

Note. Source: UNDP 2020.

does not ensure decent living conditions, especially with the price hike during the pandemic (UNICEF, 2020).

\section{Vulnerability Assessment}

The coronavirus's global impact has not been fully determined, given that this crisis has not yet ended. In Jordan, the number of confirmed cases and deaths is increasing, especially in the second phase in fall 2020, when at the peak of the crisis, the country reached 7,933 cases in a day and 60 deaths per 10,203,134 people. The increase in cases and the increase in measures to confront the pandemic have put pressure on the health sector and have economic and social consequences. Table 3 shows the number of registered cases and deaths due to the coronavirus in Jordan in 2020. In essence, the increase puts extra pressure on the health care sector, especially because the number of Jordan hospital beds per 1,000 is around 1.4 (Oxford, 2020), which means there was a limited capacity to handle the potential demand of such a crisis. Moreover, as Table 4 demonstrates, the number of health care staff physicians per 10,000 patients was fairly high, and the number of nurses and midwives was average. The health expenditure per GDP was $8.1 \%$, which is not a high percentage (United Nations Development Programme, 2020a).

The cumulative policies to contain the pandemic, essentially the lockdown and related policies, impacted the economy, trade, and each household. Evidently, the UNDP Survey (2020b) revealed that $72.5 \%$ indicated struggling to manage basic needs such as rent, food, heating, and medicine because of the lockdown; $63.3 \%$ were concerned about access to health care services; and $58.6 \%$ agreed that the pandemic and its measures will have a long-term impact. Generally speaking, Jordan is categorized as high in human development, according to the Human Development 
Index for 2019, obtaining a score of 0.729-which put Jordan at 102 out of 189 countries and territories; however, the inequality in Human Development Index is medium, at 14.7\% (United Nations Development Programme, 2020a).

As a macroeconomic fragile state, in Jordan, the unprecedented crisis has exacerbated the economic conditions that occurred due to domestic measures, the slowdown of the global economy, and trade turmoil (World Bank, 2020). The unemployment rate in Jordan increased to $23 \%$ in the second quarter of 2020 , up from $19.2 \%$ in 2019. This is the highest unemployment rate in the past 15 years (IMF, 2020). According to the International Monetary Fund (2020) the real GDP growth declined from $2 \%$ in 2019 to $-5 \%$ in 2020, the trade balance in August 2020 was $-\$ 869.2$ million, and tourism revenues decreased by $10.7 \%$ in the first quarter of 2020 (Central Bank, 2020). In the same way, the public finance indicators demonstrated that the general government net lending/borrowing percentage of the GDP was around $-7.4 \%$ in 2020, compared with $-3.3 \%$ in 2019, and the general government gross debt, as a percentage of the GDP, is 88.8 (IMF, 2020). Moreover, the inflows and the outflows of remittances in Jordan have been impacted by the pandemic. deporting expatriate workers and failing to renew residency permits negatively impacted the remittances flow. In the same vein, a number of Jordanians working abroad lost their jobs as a result of the economic hardship resulting from the policies to deal with the crisis. In essence, $14.3 \%$ of Jordanians work abroad, and their remittances contribute to $13.9 \%$ of the GDP (The World Bank, 2021). According to the World Bank (2020), the economic crisis that the pandemic caused involved migrant workers' wages and employment falling, which created a decline in remittances. The World Bank projects a decline of remittance flows in Europe and Central Asia (-16\%), the Middle East and North Africa (-8\%), and Latin America and the Caribbean $(-0.2 \%)$.

Looking into Jordan enterprises' situation, the International Labor Organization asserted that enterprises face challenges in cash flow; demand and supply reduction; disruption in the supply chain due to the pandemic's repercussions; low awareness of their eligibility for governmental support programs, especially social protection; and few labor programs, which makes Jordanian labor workers more economically vulnerable in COVID-19 conditions (Kebede et al., 2020).

Analyzing Jordan's governmental response to the pandemic demonstrates that Jordan adopted a hard approach by imposing high restrictions on movement during the full-scale and partial lockdowns, requiring wearing masks, and preventing social gatherings. Most Jordanians adhered to these restrictions, except in some individual cases; those who broke the law were penalized according the Defense Law. However, Jordan did not witness protests or demonstrations like those in other states (such as the United Kingdom and Germany) opposing the governmental response to the pandemic. Indeed, Jordanian citizens demanded that the government alleviate these measures and reopen the economy through social media, radio, and other public communication channels. Deterrent penalties also contributed to citizens' commitment; Table 5 (Defense Orders 2, 8, and 11, 2020) shows that penalties were tightened during the second wave of the crisis.

In the realm of long-distance learning, the Ministry of Education took the necessary measures to implement long-distance learning strategies and institutionalize the 
Table 5 Jordan's Penalties for Noncompliance With COVID-19 Restrictions

\begin{tabular}{|c|c|}
\hline The Act & The Penalty \\
\hline Breaking the full-scale lockdown & Imprisonment not exceeding 1 year \\
\hline Noncompliance with self-quarantine and curfew & Up to 3 years' imprisonment, $\$ 3000$ fine, or both \\
\hline Citizen noncompliance with wearing a mask & Fine of $\$ 28.20-\$ 70.50$ \\
\hline $\begin{array}{l}\text { Health care provider noncompliance with wearing } \\
\text { a mask }\end{array}$ & Fine of $\$ 141-\$ 705$ \\
\hline $\begin{array}{l}\text { Noncompliance with restrictions on social gather- } \\
\text { ings }\end{array}$ & $\begin{array}{l}\text { Imprisonment of } 3-12 \text { months, } \$ 1400-\$ 2800 \text { fine, } \\
\text { or both }\end{array}$ \\
\hline
\end{tabular}

transfer to online learning, such as through a public education platform, television channels with free access, and subsidizing Internet costs. Similarly, higher education institutions, including universities, community colleges, and intermediate colleges, adopted the transfer to nontraditional educational methods via electronic means or distance learning, which were considered acceptable for all purposes stipulated in the legislation related to higher education institutions. However, Jordan, as a developing country, has a lack of technology and technological skills, which reduces equal access to education. This is especially evident in poor regions such as villages, suburbs, and refugee camps (Alshoubaki, 2020). The second wave of the pandemic further burdened health care governance capacity, and facing increased pressure on public hospitals to manage COVID-19 cases, the government announced the seizure of any private health sector facilities for coronavirus patients under the conditions of the emergency law declared in March 2020 (Defense Order 23).

The socioeconomic repercussions of the pandemic required Jordan's government to formulate assistance programs to help those who lost their jobs or closed their businesses due to the current conditions. For example, the number of workers whose wages were reduced by $50 \%$ was 3,704 in the second month of the pandemic, and 8,439 businesses had closed (UNICEF, 2020). Tourism was a major source of employment and GDP before the pandemic (19.4\% of the GDP); however, the pandemic caused a decline in revenues transferred to the treasury by $81 \%$, an estimated loss of $\$ 4$ billion (IMF, 2021). The UNDP (2020) reported that the vast majority of Jordanians lost their jobs and experienced low cash flow, especially craftspeople, daily wage workers, and independent businesses. Financial support programs are in place to deal with socioeconomic vulnerability through the National Aid Fund to allocate funds for poor and fragile families living under harsh conditions due to a lack of income (UNICEF, 2020). The provided cash assistance ( $\$ 70$ to $\$ 190$ for 3 months) is not sufficient, especially while prices and hardships in finding alternative income sources are increasing (UNICEF, 2020). Moreover, the application and distribution of these assistance programs through electronic wallets creates difficulty in access for beneficiaries who already lack technological capacity, advanced devices, and Internet connections (Alshoubaki, 2020).

The social and economic resilience and capacity-building policies and programs are subject to expansion in criteria timelines to enable beneficiaries' maximum utilization. In this regard, Defense Orders 18, 19, and 24 (2020) extended the deadline 
of the Empowerment I Program and permitted Supporting Program I to be utilized in combination with other programs. Moreover, the government has made efforts to include some previously marginalized strata, such as residents of the Gaza Strip and children of Jordanian women residing in Jordan, to allow them to benefit from these programs. In fact, individuals in these categories suffer from a lack of recognition in Jordanian laws and policies, which made this step a paradigm shift in government inclusion orientation.

\section{Conclusion and Remarks}

The aim of this study was to provide an understanding of the Jordanian government's response to the first year of the pandemic. It demarcates the government policies to deal with the crisis in light of the fragile health care system and vulnerable economic situation. Mainly, this study sought to answer two main inquiries in terms of a vulnerability assessment of the health care system and economic situation and to address Jordan's approach in responding to the pandemic crisis. In so doing, it used the interpretive policy analysis approach to looking at governmental documents. The analysis of the official documents and the defense orders, as well as incorporating the facts and realities about Jordan's situation during the pandemic, inform the perspective that Jordan sought contextual policies to provide health care protection, social protection, the continuation of basic services, and economic protection and recovery. This study shows that the Jordan government has utilized a hard approach in managing the crisis. Jordan mandates wearing masks and gloves, maintaining physical distance, intensive testing, and epidemiological tracing. Using lockdown measures, restricting public events and congregation, and controlling traveling to reduce the risk of infections protects the people. Jordan imposed fines and stiffened the sanctions at the peak of the crisis. Jordan adopted social programs and plans to alleviate the poor conditions that Jordanian households suffered from due to the pandemic-especially those people who lost their jobs or whose work was suspended during the pandemic. In terms of economic conditions, Jordan supported the private sector organizations and the most affected sector to maintain their sustainability, as well as to assist in their recovery from the pandemic, which has not ended yet. The Jordan government implemented different extensions and inclusion criteria for the policies and programs due to the complexity and uncertainty of this pandemic. In the end, the authors recommend future researchers to assess the impact of social and economic policies on the beneficiaries and to assess the overall national plans and policies of this crisis in Jordan.

\section{Declarations}

Financial interests Authors declare that they have no financial interests.

Research involving human and animal rights The authors confirm that this research does not involve human participants and/or animals and all the analysis is built upon published documents. 
Conflicts of interest The authors have no conflicts of interest to declare.

\section{References}

Alshoubaki, W. (Nov. 30, 2020). A Reality Check of Zaatari Camp in the Time of Coronavirus: A Contextual Demarcation [Published in Italian: Zaatari, Giordania: la realtà di un campo profughi al tempo del Coronavirus]. Retrieved from http://www.mondopoli.it/2020/11/30/zaatari-giord ania-la-realta-di-un-campo-profughi-al-tempo-del-coronavirus/.

Baldwin R., \& Di Mauro B. W. (2020) Mitigating the COVID economic crisis: Act fast and do whatever it takes. Centre for Economic Policy Research Press.

Ben Mimoune, N., Abouzzohour, Y., \& Goldner, T. (2020). Policy and institutional responses to COVID-19 in the Middle East and North Africa: Jordan. Brookings Doha Center. Retrieved from https://www.brookings.edu/research/policy-and-institutional-respo nses-to-covid-19-in-the-middle-east-and-north-africa-jordan/

Boin, A. (2005). From crisis to disaster: Towards an integrative perspective. In R. W., Perry, \& E. L., Quarantelli (Eds), What is a disaster? New answers to old questions (pp. 280-285). International Research Committee on Disasters.

Browne, J. Coffey, B. Cook, K. Meiklejohn, S., \& Palermo, C. (2018). A guide to policy analysis as a research method. Health Promotion International, 1-13 doi: https://doi.org/10.1093/heapro/ day052

Bryman, A. (2016). Social research methods (5 $5^{\text {th }}$ ed.). Oxford University Press.

Capano, G. (2020). Policy design and state capacity in the COVID-19 emergency in Italy: If you are not prepared for the (un)expected, you can be only what you already are. Policy and Society, 39(3), 326-344. https://doi.org/10.1080/14494035.2020.1783790

Capano, G., Howlett, M., Jarvis, D. S. L., Ramesh, M., \& Goyal, N. (2020). Mobilizing policy (in)capacity to fight COVID-19: Understanding variations in state responses. Policy and Society, 39(3), 285308. https://doi.org/10.1080/14494035.2020.1787628

Christensen, T., \& Lægreid, P. (2020). Balancing governance capacity and legitimacy: How the Norwegian government handled the COVID -19 crisis as a high performer. Public Administration Review, 80(5), 774-779. https://doi.org/10.1111/puar.13241

Colebatch, H. K. (2002). Policy Berkshire. Open University Press.

Davidovitz, M., Cohen, N., \& Gofen, A. (2020). Governmental response to crises and its implications for street-level implementation: Policy ambiguity, risk, and discretion during the COVID-19 pandemic. Journal of Comparative Policy Analysis: Research and Practice, 23(1), 120-130. https://doi.org/10. 1080/13876988.2020.1841561

Defense Law No. (13) for the Year 1992. (Jordan)

Fakhruddin, B., Blanchard, K., \& Ragupathy, D. (2020). Are we there yet? The transition from response to recovery for the COVID-19 pandemic. Progress in Disaster Science, 7, 1-5. https://doi.org/10. 1016/j.pdisas.2020.100102

Farazmand, A. (2007). Learning from the Katrina crisis: A global and international perspective with implications for future crisis management. Public Administration Review, 67(1), 149-159. https:// doi.org/10.1111/j.1540-6210.2007.00824.x

Farazmand, A. (2009). Hurricane Katrina, the crisis of leadership, and chaos management: Time for trying the 'surprise management theory in action. Public Organization Review, 9(4), 399-412. https:// doi.org/10.1007/s11115-009-0099-2

Farazmand, A., \& Danaeefard, H. (2021). Iranian government's responses to the coronavirus pandemic (COVID-19): An empirical analysis. International Journal of Public Administration, 1-12. https:// doi.org/10.1080/01900692.2021.1903926

Fischer, F. (2003). Reframing Public Policy: Discursive Politics and Deliberative Practices. Oxford University Press.

Fischer, F., Torgerson, D., Durnova', A., \& Orsini, M. (2015). Handbook of Critical Policy Studies. Edward Elgar Publishing.

Ghosh, A., Nundy, S., \& Mallick, T. K. (2020). How India is dealing with COVID-19 pandemic. Sensors International, 1, 100021. https://doi.org/10.1016/j.sintl.2020.100021 
Goyal, N., \& Howlett, M. (2021). "Measuring the mix" of policy responses to COVID-19: Comparative policy analysis using topic modelling. Journal of Comparative Policy Analysis: Research and Practice, 23(2), 250-261. https://doi.org/10.1080/13876988.2021.1880872

Hague, R., \& Harrop, M. (2006). Comparative government and politics: an introduction (6 ${ }^{\text {th }}$ ed.). Palgrave Macmillan.

Hajer, M., \& Wagenaar, H. (2003). Deliberative policy analysis: Understanding governance in the network society. Cambridge University Press.

Hale, T., Angrist, N., Goldszmidt, R., Kira, B., Petherick, A., Phillips, T., Webster, S., Cameron-Blake, E., Hallas, L., Majumdar, S., \& Tatlow, H. (2020). A global panel database of pandemic policies (Oxford COVID-19 Government Response Tracker). Nature Human Behaviour. https://doi.org/10. 1038/s41562-021-01079-8

Health Care Accreditation Council (2020, 14 June). Control of COVID 19 in Jordan: Governance, Decentralization, and Quality. https://www.youtube.com/watchv $=2 \mathrm{~m} 1 \mathrm{pH} 17 \mathrm{KhRI} \&$ feature=emb_title

Imtyaz, A., Haleem, A., \& Javaid, M. (2020). Analysing governmental response to the COVID-19 pandemic. Journal of Oral Biology and Craniofacial Research, 10(4), 504-513. https://doi.org/10. 1016/j.jobcr.2020.08.005

Jordan Prime Ministry. (2020). Notices and Instructions for Orders of Defense Law No. 13 of 1992. http://www.pm.gov.jo/content/.html

Kebede, T. A., Stave, S. E., Kattaa, M, \& Prokop, M. (2020). Impact of the COVID-19 pandemic on enterprises in Jordan. International Labour Organization, UNDP and FAFO. Retrieved From https://www.jo.undp.org/content/jordan/en/home/presscenter/pressreleases/counting-the-cost-ofcovid-19--impact-of-the-pandemic-on-enterpr.html

Kim, Y.-gyun, \& Sohn, H.-G. (2019). Disaster risk management in the Republic of Korea. Springer.

Kovacevic, M., \& Jahic, A. (2020) Covid-19 And Human Development: Exploring Global Preparedness and Vulnerability. United Nations Development Programme [UNDP]. Retrieved from http://hdr. undp.org/en/content/covid-19-human-development-exploring-preparedness-vulnerability

Lone, S. A., \& Ahmad, A. (2020). COVID-19 pandemic - an African perspective. Emerging Microbes \& Infections, 9(1), 1300-1308. https://doi.org/10.1080/22221751.2020.1775132

Massadeh, A. E. (1999). The structure of public administration in Jordan: A constitutional and administrative law perspective. Arab Law Quarterly, 14(2), 91-111.

Ministry of Health. (2020). COVID-19 Updates in Jordan. Retrieved From https://corona.moh.gov.jo/en/ MediaCenter/1228

Moe, L. T., \& Pathranarakul, P. (2006). An integrated approach to natural disaster management. Disaster Prevention and Management: An International Journal, 15(3), 396-413. https://doi.org/10.1108/ 09653560610669882

Oh, J., Lee, J.-K., Schwarz, D., Ratcliffe, H. L., Markuns, J. F., \& Hirschhorn, L. R. (2020). National response to COVID-19 in the Republic of Korea and lessons learned for other countries. Health Systems \& Reform, 6(1). https://doi.org/10.1080/23288604.2020.1753464

Oxford, Our world in Data (2020). Jordan: Coronavirus Pandemic Country Profile. Retrieved from https:// ourworldindata.org/coronavirus/country/jordan?country $=\sim \mathrm{JOR}$

Petak, W. J. (1985). Emergency management: A challenge for public administration. Public Administration Review, Special Issue, 45, 3-7.

Scott, J. (1990). A Matter of records: Documentary sources in social research. Polity Press. The Civil Defense Law No. (18) for Year1999. 1. (Jordan)

The International Monetary Fund [IMF] (Jan. 12, 2021) First Review Under the Extended Fund Facility Arrangement and Request for a Waiver of Nonobservance and Modifications of Performance Criteria, and Rephasing of Access-Press Release; Staff Report; and Statement by the Executive Director for Jordan. IMF Country Report No. 21/11. Retrieved from https://www.imf.org/en/Publications/ CR/Issues/2021/01/11/Jordan-First-Review

The World Bank (2020). COVID-19 to Plunge Global Economy into Worst Recession since World War II. Press Release NO: 2020/209/EFI. Retrieved from https://www.worldbank.org/en/news/pressrelease/2020/06/08/covid-19-to-plunge-global-economy-into-worst-recession-since-world-war-

Thompson, C., Lewis, D., Greenhalgh, T., Taylor, S., \& Cummins, S. (2013). A health and Social Legacy for East London: Narratives of Problem and Solution Around London 2012. Sociological Research Online, 18(2), 1. https://doi.org/10.5153/sro.2966

UNICEF (2020). Jordan's National Social Protection Response During Covid-19. Retrieved from https:// www.unicef.org/jordan/media/3921/file/Jordan's\%20National\%20SP\%20Response\%20During\% 20COVID-\%20UNICEF\%20\%20JSF.pdf 
United Nations Development Programme (2020a). Covid-19 And Human Development: Assessing The Crisis, Envisioning The Recovery. Retrieved from http://hdr. undp.org/en/hdp-covid

United Nations Development Programme (2020b). COVID-19 Impact on Households in Jordan: A Rapid Assessment. Retrieved from https://reliefweb.int/report/jordan/covid-19-impact-households-jordanrapid-assessment-may-2020.

United Nations. (2004). Hashemite Kingdom of Jordan: Public Administration Country Profile.

Upadhaya, B., Wijethilake, C., Adhikari, P., Jayasinghe, K., \& Arun, T. (2020). COVID-19 policy responses: Reflections on governmental financial resilience in South Asia. Journal of Public Budgeting, Accounting \& Financial Management, 32(5), 825-836. https://doi.org/10.1108/ jpbafm-07-2020-0130

Vardavas, C., Odani, S., Nikitara, K., El Banhawi, H., Kyriakos, C., Taylor, L., \& Becuwe, N. (2021). Public perspective on the governmental response, communication and trust in the governmental decisions in mitigating COVID-19 early in the pandemic across the G7 countries. Preventive Medicine Reports, 21, 101252. https://doi.org/10.1016/j.pmedr.2020.101252

Yanow, D. (2000). Conducting interpretive policy analysis. SAGE Publications.

Publisher's Note Springer Nature remains neutral with regard to jurisdictional claims in published maps and institutional affiliations. 